Ethiopian Journal of Environmental Studies \& Management 7(6): 628 - 634, 2014.

ISSN:1998-0507

doi: http://dx.doi.org/10.4314/ejesm.v7i6.5

Submitted: July 11, 2014

Accepted: October 04, 2014

\title{
SPATIAL DYNAMICS OF FUEL WOOD EXPLOITATION IN DELTA STATE, NIGERIA
}

\author{
*IGBEN, J.L., IHAYERE, C.A. AND OHIEMBOR, O.M. \\ Department of Environmental Science, Western Delta University, P.M.B.10 Oghara, Delta State, \\ Nigeria
}

\begin{abstract}
This study examined the spatial and temporal changes in fuel wood exploitation as a result of environmental degradation, between 2008 and 2013 in Delta State, Nigeria. It utilised data from both primary and secondary sources. Primary data were obtained from a survey of selected settlements using a questionnaire. The multi-stage sampling technique was used to select sample for the study. The first stage involved the random selection of one rural settlement each from three ecological zones. The second stage involved enumeration of 362 household heads engaged in fuel wood collection in selected settlements. The questionnaire covered impact of fuel wood exploitation on the environment and variations in distances from residence to points of exploitation between 2008 and 2013. The pair-wise student t-test was used to analyse the data collected for the study. There were significant dynamics in distances ( $t=-16.078, d f=361$, $p<0.05)$ over the two-time period. The study recommends the development of alternative energy sources for sustainable use of the environment
\end{abstract}

Key Words: Fuel wood exploitation, environmental degradation, deforestation, Primary occupations, Sustainabilty, Delta State

\section{Introduction}

Fuel wood is the major source of energy in the rural areas of Nigeria, dominated by primary occupations such as agriculture, fishing, lumbering, hunting, and tapping of rubber trees and raffia palm, and other occupations that are involved in the exploitation of resources from the biotic component of the ecosystem. Such activities include collection of non-timber forest products like bamboo, palm nuts, screw pines and thatches, snails, fruits and herbs for medicinal purposes. The output from these primary occupations is processed by the use of fuel wood, sometimes call fire-wood. For instance, fuel wood is used to roast fishes and games derived from fishing and hunting respectively, and in the distillation of local gin, popularly known as "Ogogoro" from wine obtained from raffia palm (Raphia hookeri). In addition, fuel wood is used for cooking, lighting, heating of bakery earthen ovens and houses during the rainy and "harmattan" seasons. Raw wood input is also used for the production of charcoal, which serves as substitute for fuel wood in urban areas. Thus, fuel wood has both domestic and commercial uses.

The diverse use of fuel wood coupled with the fact that it is the sole source of domestic energy for about $80 \%$ of rural dwellers in Nigeria and inadequate supply of electricity and kerosene for domestic and industrial uses leads to pressure and high demand for the resource; hence, its exploitation has been identified as a major

*Corresponding Author: Igben, J.L..

Email: joma_igben@yahoo.com 
primary occupation in the rural areas, which constitute the greater proportion of the Nigerian population (Cecelski et al., 1979; Williams, 1998; Igben, 2012). Fuel wood is unrestrainedly exploited from the surrounding forest vegetation by felling and cutting trees into logs. Sometimes, dead trees which provide media for mushroom growth are also used as fuel wood, thus depriving the environment of its diversity and benefits to man.

In the study area, dead trees provide growth medium for numerous species of wild mushroom which are able to convert huge lignocellulose biomass wastes into human food consume especially among rural dwellers. Examples of such edible mushrooms include Agaricus bisporus, Volvoriella volvacea, Lentinulaedodes, Auricularia auricular, T. robustus, T.globulus, $\quad V$. esculenta and young sporophores of tuber-regium. (Oso, 1977; Jonathan and Fasidi, 2003; Alofe et al., 1998; Chang and Miles, 2004). In addition, some mushrooms such as Ganoderma lucidum, Grifola frondosa, Agaricu blazei and Schizophyllum commune which are destroyed in the process of fuel wood collection produce biomedical products and are therefore used as medicines by the local population (Yang et al., 2001).

The mode of exploitation and the type of wood used as fuel depend on ecological zones. For instance, in the mangrove swamp ecological zone dominated by mangrove (Rhizophora race mosa), the main fuel wood type is mangrove and Conocarpus erectus. Similarly, in the fresh water swamp and the lowland rainforest ecological zones, Ceiba pentadra, Lophira alata, Chlorophora excelsa, Pentacenthra macrophylla, Pentaclethera macroloba, Mitragyna ciliata, Entandrophragma cylindricum and other woody species are felled and utilized by the low income group that cannot afford alternative sources of energy. The felling of rubber trees for fuel wood in the study area is the consequence of the economic downturn in the price of rubber in the world market, which has made most rubber tappers to explore other means of livelihood.

Fuel wood exploitation in the study area is seen as one of human activities that degrades the physical environment. The literature is replete with studies on environmental degradation induced by this activity. Some of these studies focused on the rationale for its exploitation (Odii and Mokwuenye, 2003; Rim-Rukeh, 2009), while others concentrate on the environmental effects of fuel wood exploitation (UNEP/ISRC, 1990; Baliya, 1999; Odii et al., 1999; Odii and Mokwuenye, 2003; Babanyara and Saleh, 2010; Ikurekong et al., 2009; Okoye and Ezeonyejiaku, 2010; Bello, 2010; Audu, 2013). For instance, Odii et al. (1999) identified collection of vegetation among other human actions that leads to desertification and deforestation.

Similarly, Odii and Mokwuenye (2003) asserted that utilization of fuel wood has resulted in serious ecological problem of deforestation, erosion, loss of topsoil, infertility and poor crop yield in most part of Nigeria. Still on the impact of fuel wood exploitation on the physical environment, Ikurekong et al. (2009) stated "the exploitation of fuelwood among the rural and coastal fishing communities in Nigeria has been an inevitable consequence of human existence. This has been intensified by the inhabitant's inaccessibility to other sources of energy. The major consequence of this has been the depletion of major forest resource as well as environmental degradation". Furthermore, studies by Okoye and Ezeonyejiaku (2010), and Audu (2013) identified the exploitation and consumption of fuel wood as a major cause of desertification in Nigeria. Thus the 
exploitation of fuel wood results in environmental degradation.

In spite of the wide spread use and exploitation of fuel wood in Nigeria, particularly in the rural areas, a critical review of the literature shows that the spatial and temporal variations in its exploitation, as a result of environmental degradation, have not been studied. In the light of the foregoing, this study empirically examines the spatio-temporal variations in fuel wood exploitation in Delta State as a resultant effect of environmental degradation. Its specific objective is to determine the dynamics in distance from residence to points of fuel wood exploitation between 2008 and 2013 in the study area.

\section{Methodology \\ Study Area}

Delta State is one of the thirty six states in Nigeria. The state lies roughly between Latitudes $5^{\circ} 00^{\prime}$ and $6^{\circ} 30^{\prime}$ north and Longitudes $5^{\circ} 00^{\prime}$ and $6^{\circ} 45^{\prime}$ east, over an area of 22,159 square kilometres in the NigerDelta area of the country. The state is bordered in the north by Edo State, by Ondo State to the northwest, Anambra State to the east and Bayelsa State to the southeast. On its southern flank is the Atlantic Ocean, which covers approximately 160 kilometres of the state's coastline. The state has 25 political divisions called Local Governments Areas, and its capital of the state is Asaba.

The 2006 provisional national population census put the population of Delta State at 4,098, 391 persons, made up of 2,074,306 males and 2,024,085 females (NPC, 2006). The population consists of many diverse, but related ethnic groups of the Urhobo, Ijaw, Isoko and Itsekiri in the southern part of the state and Ibo and Ukwuani in the north. Close to 25 per cent of the total population lives mainly in towns and cities (NPC, 1991).
The main occupations of the people of the state are land intensive and dependent upon the ecological zones. The state comprises four ecological zones, of coastal barrier island or ridges, mangroves, fresh water swamp forest and lowland rainforest. These zones were classified by Ikporukpo (1996) into two, namely, the outer delta; which comprise muddy sheltered creeks, deltas, brackish and or strong tidal waters characterized by mangrove (Rhizophora race mosa) as the most common plant. Associated with this zone are occupations such as fishing and trading. The inner delta, is made up predominantly of swamp rainforest which is not as wet. The zone comprises wet lowland evergreen rainforest in the north and mangrove forests in the south. The main occupations in this zone are land based and they include farming, fishing, and hunting, tapping of rubber, and raffia palm, mining and trading. Consequently, the state is predominantly rural and there is the preponderance of primary occupations. With respect to this study however, the state is divided into three zones namely mangroves, fresh water swamp forest and lowland rainforest. This division is based on the fact that the coastal barriers and ridges along the shore of the Atlantic Ocean is a transient zone and contain little or no vegetation cover.

\section{Research Design}

The causal-comparative research design often referred to as ex-post facto was employed to collect primary data for the study. This design reconstructs the past by asking retrospective questions on an earlier period and comparing it with the present situation (Frankfort-Nachmias and Nachmias, 1996). The choice of this design enabled the researcher to collect information on the distances traversed by respondents to points of fuel wood exploitation in 2008 and 2013. 


\section{Population and Sample}

Multi-stage sampling technique was used to select sample for the study. The first stage is the random selection of one settlement each from a list of rural settlements in the three ecological zones in the study area using the table of random digits. The settlements selected are; Ugborodo in the mangrove swamp forest, Egini in the fresh water swamp zone, and Ovade in the lowland rainforest zone.

The second stage involved the identification of households engaged in fuel wood exploitation in each selected settlement. A total of 362 households were enumerated and their heads or representatives interviewed in the three settlements. The questionnaire used for the study was designed to cover all facets of the study, which include the socio-economic and demographic characteristics of the respondents and the changes in distance traverse in the collection of fuel wood between 2008 and 2013. Data collected for the study were coded and frequencies of occurrence of events and percentages were worked out and presented in tables. The pairwise Student t-test was used to test the significant difference in distance between the two-time periods. The use of this test was predicated on the nature of the data collected. The object of analysis of data was on the difference in individual response for the two time period. The mean between individual pair is tested rather than the differences between the means. The process of data analysis was facilitated by the use of the Statistical Package for Social Sciences (SPSS).

\section{Results and Discussion \\ Socio-demographic and Economic Characteristics of Respondents}

Of the 362 respondents interviewed in the three sampled settlements for the study, 216 respondents representing $59.7 \%$ are females while males constitute 146 respondents or 40.3 per cent. Furthermore, the majority of the respondents in the selected settlements are Christians, who accounted for 78.4 per cent. While 11.6 per cent practise African Traditional Religions (ATR).This finding is expected because Christianity is the dominant religion in the state (Imoroa, 2000). In addition, 66.4 per cent of the sample population had no form of formal education. While 20.2 per cent and 10.5 per cent had primary and secondary education respectively, 0.8 per cent of the sample had vocational training in motor-cycle and motorized-saw repairs, tailoring and hair dressing; only 2.1 per cent had tertiary education such as Ordinary National Diploma (OND) and University degrees. Moreover, 56 respondents representing $15.45 \%$ of the sample population exploit fuel wood for commercial purposes.

Spatial Changes in Fuel Wood Exploitation between 2008 and 2013

Tables 1 and 2 show the distances exploiters of fuel wood resources traverse to points of work in 2008 and 2013 respectively. The tables reveal that there were considerable changes in the distances to points of fuel wood exploitation between the periods under study. Table 1 depicts that in 2008, eighty (80) respondents representing 22.1 per cent moved less than $1 \mathrm{~km}$ from their residence to points of exploitation, their number decreased to 36 respondents or 9.9 per cent in 2013. Similarly, there were decreases from 116 respondents $(32.0 \%)$ to 29 respondents or 8.0 per cent and from 101 respondents $(27.9 \%)$ to 47 respondents or $13.0 \%$ for distances of $1.0-1.4 \mathrm{~km}$ and $1.5-$ $2.0 \mathrm{~km}$ respectively in 2008 and 2013.

In contrast, there were increases in the number of respondents from 24 respondents $(6.6 \%)$ to 54 respondents $(14.9 \%)$ and 12 respondents $(3.3 \%)$ to 88 respondents 
$(24.3 \%)$ for $2.0-2.4 \mathrm{~km}$ and $2.5-3.0 \mathrm{~km}$ categories respectively. The same trend is noticeable for distances farther away, from 15respondents $(4.1 \%)$ to 51respondents or $14.1 \%$ to 51 respondents or $14.1 \%$ and from 7 respondents to 34 respondents in the $3.0-3.4 \mathrm{~km}$ and $3.5-4.0 \mathrm{~km}$ groups respectively. Also, there was increase in the number of respondents who traverse more than $4 \mathrm{~km}$ from 7 respondents $(1.9 \%)$ in 2008 to 23 respondents $(6.4 \%)$ in 2013.

Different instruments such as motorized saws, handsaws, axes, chisels and cutlasses, are used in felling and hewing wood for domestic and commercial uses. Human porters, bicycles, wheel-barrows and pickup vans are used to convey woods to points of sale, where they are stacked in 'chords' on land, while canoes and in few cases motorized boats are used in riverine areas. The spatial changes in fuel wood exploitation due devastated environment, as depicted in Table 3, was tested statistically using the Student's t-test. The result shows that the computed pair-wise Student's t-test value of 16.078 at 361 degree of freedom is significant at 0.05 confidence level. Therefore, there was a significant spatiotemporal change in fuel wood in the study area between 2008 and 2013.

The implication of the above findings is that workers in this activity have to move longer distances to their points of activities as postulated in the multi-phasic theory by
Davis (1963). The theory argue that a decline in the resources base of the population as a result of environmental deterioration increase pressure on available resources. The population, in response to pressure would devise alternative ways of survival. Moving longer distances to points of economic activity is one of numerous options.

\section{Conclusion and Recommendation}

The study revealed that there were significant spatial changes in the exploitation of fuel wood between 2008 and 2013 in the study area as a result of environmental deterioration. The surrounding woody vegetation is very critical to the activities of the fuel wood exploiters; hence, any degradation in the form of deforestation or general deterioration of vegetation due to other human activities or natural disasters will adversely affect spatial organisation of their activities.

Following from the above, the study recommends that alternative sources of energy such as kerosene, gas and electricity should be made more available and affordable. This would help to promote sustainable use of the environment by reducing the rate of commercial or domestic exploitation of wood resources from the vegetation. In addition, exploiters of fuel wood resources should be educated on the need to use alternative energy sources and promote environmental sustainability.

Table 1: Distance to point of activity from residence 2008

\begin{tabular}{lll}
\hline Distance & Frequency & Percentage \\
\hline Less than $1 \mathrm{~km}$ & 80 & 22.1 \\
$1 \mathrm{~km}-1.4 \mathrm{~km}$ & 116 & 32.0 \\
$1.5 \mathrm{~km}-2 \mathrm{~km}$ & 101 & 27.9 \\
$2 \mathrm{~km}-2.4 \mathrm{~km}$ & 24 & 6.6 \\
$2.5 \mathrm{~km}-3 \mathrm{~km}$ & 12 & 3.3 \\
$3 \mathrm{~km}-3.4 \mathrm{~km}$ & 15 & 4.1 \\
$3.5 \mathrm{~km}-4 \mathrm{~km}$ & 7 & 1.9 \\
More than $4 \mathrm{~km}$ & 7 & 1.9 \\
Total & 362 & 100.0 \\
\hline
\end{tabular}


Table 2: Distance to points of activity from residence 2013

\begin{tabular}{lll}
\hline Distance & Frequency & Percentage \\
\hline Less than $1 \mathrm{~km}$ & 36 & 9.9 \\
$1 \mathrm{~km}-1.4 \mathrm{~km}$ & 29 & 8.0 \\
$1.5 \mathrm{~km}-2 \mathrm{~km}$ & 47 & 13.0 \\
$2 \mathrm{~km}-2.4 \mathrm{~km}$ & 54 & 14.9 \\
$2.5 \mathrm{~km}-3 \mathrm{~km}$ & 88 & 23.3 \\
$3 \mathrm{~km}-3.4 \mathrm{~km}$ & 51 & 14.1 \\
$3.5 \mathrm{~km}-4 \mathrm{~km}$ & 34 & 9.4 \\
More than $4 \mathrm{~km}$ & 23 & 6.4 \\
Total & 362 & 100.0 \\
\hline
\end{tabular}

Table 3: Pair-wise Student's t-test

\begin{tabular}{|c|c|c|c|c|c|c|c|c|}
\hline & \multicolumn{5}{|c|}{ Paired Differences } & \multirow[b]{3}{*}{$\mathrm{T}$} & \multirow[b]{3}{*}{ df } & \multirow{3}{*}{$\begin{array}{l}\text { Sig. (2- } \\
\text { tailed) }\end{array}$} \\
\hline & \multirow[b]{2}{*}{ Mean } & \multirow{2}{*}{$\begin{array}{l}\text { Std. } \\
\text { Deviation }\end{array}$} & \multirow{2}{*}{$\begin{array}{l}\text { Std. Error } \\
\text { Mean }\end{array}$} & \multicolumn{2}{|c|}{$\begin{array}{l}95 \% \text { Confidence } \\
\text { Interval of the } \\
\text { Difference }\end{array}$} & & & \\
\hline & & & & Lower & Upper & & & \\
\hline $\begin{array}{l}\text { Pair } 1 \text { Distance to point of activity } \\
\text { from residence } 2008 \text { - } \\
\text { Distance to point of activity } \\
\text { from residence } 2013\end{array}$ & -1.804 & 2.135 & .112 & -2.025 & -1.583 & -16.078 & 361 & .000 \\
\hline
\end{tabular}

\section{References}

Audu, E.B. (2013). Fuel wood consumption and desertification in Nigeria. International Journal of Science and Technology, Vol. 3, No.1 January

Babanyara, Y. Y. and Saleh, U.F. (2010). Urbanization and the choice of fuel wood as a source of energy in Nigeria. Journal of Human Ecology, 31(1):1926.

Baliya, H.H. (1999). Fuel wood consumption: A constraint to rural development in Borno State. In Englham E V. T. (ed) Population and Development in Bornu State, Nigeria

Bello, N.J. (2010). Climate Change: Implications for food production and security. In, Climate change impact adaptation: Development Issues. Nigerian Meteorological Society, Pg. 4
Chang, S.T. and Miles, P.G. (2004). Mushrooms: Cultivation, nutritional value, medicinal effects and environmental impact. Boca Raton, Florida, CRC Press

Cecelski, E., Dunkerly, J and Ramsay, R. (1979). Household energy and the poor in the third world. In, Resources for the future, Washington D.C.

Frankfort-Nachmias, C. and Nachmias, D. (1996). Research methods in the social sciences. London:Arnold.

Igben, J.L. (2012). Environmental degradation and occupational dynamics of labour force in Delta State, Nigeria. Sacha Journal of Environmental Studies, 2(1): 80-90.

Ikporukpo, C.O. (1996). Federalism, political power and economic power game; conflict over access to petroleum resources in Nigeria. Environment and 
Planning C, Government and Policy, 14 (2):159-177.

Ikurekong, E.E., Esin, J.O. and Mba, A.C. (2009). Rural fuel wood exploitation in Mbo Local Government Area - A Nigerian CoastalSettlement. Ethiopian Journal of Environmental Studies and Management, 2(3): 44-55.

Imoara, N. O.2000. Delta State. Nigeria. A people united, a future assured. In, A. B. Mamman, J. O. Oyebanji and S.W. Petters.( Eds).Vol. 2, Calabar, Gabumo Publishing.

Jonathan, S.G. and Fasidi, I.O. (2003). Physiological studies on Schizophyllum commune (Fr. Ex. Fr.) a Nigerian edible mushroom. Biosci.Res.Com.,15(1):1522.

National Population Commission (NPC) 2006. Provisional population census report.

Odii, M.A.C.A. and Mokwuenye, J.N. (2003). Minimizing fuel wood consumption through the evolution of hot stone cooker as an alternative domestic energy supply. JASR,3(1): 4054

Odii, M.A.C.A., Asobaka, C.C. and Ugochukwu, A.I. (1999). Determinants of women mobilization for efficient resource management, environmental sustainability. Journal of Erosion and Environmental Degradation, 118-127

Okoye, C.O. and Ezeonyejiaku, D.C. (2010). Desertification in the dry lands of Nigeria: causes, consequences and solutions. Journal of the Faculty of Environmental Sciences, Nnamdi Azikiwe University, Awka, 1(1): 49-51

Rim-Rukeh, A. (2009). Environmental Science: An introduction. Ibadan, Kraft Books Limited

UNEP/ISRIC 1990. World Map of the Status of Human-Induced Soil Degradation. Wageningen, the Netherlands.

Williams, C.E. (1998). Reaching the African Female Farmers Innovative Approaches; Success and Challenges for the future. Seminar paper presented to the international workshop on Women Agricultural Intensification and Household food Security at the University of Cape Coast, Ghana, $25^{\text {th }}$ $-28^{\text {th }}$, June

Yang, B.K., Jeong, S.C., Park, J.B., Cho, S.P., Lee, S.D., Yun, J.W., Lim, W.J. and Song, C.H. (2001). Swimming endurance capacity of mice after administration of exo-polymerproduced from submerged mycelial culture of Ganoderma lucidum. Journal; of Microbiology and Biotechnology, 11: 902 - 90 . 